\title{
RESEARCH OF THE CONTENT OF PHENOLIC COMPOUNDS, FLAVONOIDS AND IODINE IN CHOCOLATE USING NON-TRADITIONAL RAW MATERIALS
}

\author{
YanaBiletska \\ PhD, Associate Professor \\ monika3384@ukr.net \\ Olha Bilovska \\ o.bilovska@karazin.ua \\ Anna Krivtsova ${ }^{1}$ \\ rtb@karazin.ua \\ Iryna Huzhva \\ monika3384@ukr.net
}

Alla Nekos

Doctor of Geographical Sciences, Professor

Department of Environmental Safety and Environmental Education

Educational and Scientific Institute of Ecology

a.nekos999@gmail.com

\author{
${ }^{1}$ Department of International Ecommerce and Hotel and Restaurant Business ${ }^{2}$ \\ ${ }^{2} V$. N. Karazin Kharkiv National University \\ Svobody sq., 4, Kharkiv, Ukraina, 61022
}

\begin{abstract}
A study to determine the total content of phenolic compounds, flavonoids and mass fraction of iodine in chocolate using non-traditional raw materials has been conducted. The object of the study was chocolate products, containing stevioside, erythrol, germinated soy flour, enriched with iodine.

Carrying out this set of studies is important because it will determine the content of phenolic compounds, flavonoids and iodine in the developed chocolate. Based on the obtained patterns, it is possible to determine the percentage of satisfaction of the recommended daily requirement and to set the recommended amount of consumption of the developed product per day.

As a result of research, it has been found, that the total content of phenolic compounds in the control type of chocolate per 198 $\mathrm{mg}$ of GA/100 $\mathrm{g}$ of the initial raw material is less compared to the sample of chocolate, where non-traditional raw materials were used. The results of the study correlate with the results of determining the total content of flavonoids. The developed types of chocolate exceed control samples by $229 \mathrm{mg}$ of $\mathrm{C} / 100 \mathrm{~g}$ of the initial raw material. That satisfies $88.6 \%$ of the recommended daily amount. It has been found, that the developed type of chocolate is a carrier of iodine in the amount of $63 \mu \mathrm{g} / 100 \mathrm{~g}$. In the control sample of chocolate there were found only traces of mass fraction of iodine. It has been determined, that the use of germinated soy flour, enriched with iodine in the amount of $10 \%$, due to the reduction of cocoa mass satisfies $42 \%$ of the recommended daily amount of iodine for a woman aged $30 \ldots 40$ years of average labor intensity.

The obtained results are useful and important because they will allow to develop recommendations for the consumption of chocolate using non-traditional raw materials. What will affect the solution of an important social problem - maintaining high efficiency, confrontation with environmental factors under the pandemic due to the influx of test substances.
\end{abstract}

Keywords: chocolate, stevioside, erythrol, germinated soy flour enriched with iodine.

DOI: $10.21303 / 2504-5695.2021 .001875$

\section{Introduction}

According to the forecasts of the world's leading experts in the field of nutrition and medicine, the issue of developing technologies for special dietary products is quite acute and is relevant [1]. Modern research focuses on the production of specialized foods enriched with essential microelements $[2,3]$. 
Chocolate is a popular confectionery product among children and adults [4]. Research work [5] proves the positive properties of chocolate as a product for specialized nutrition due to the content of phenolic compounds and flavonoids. Deterioration of the human body is associated with the deterioration of its own antioxidant defense system. Deficiency of phenolic compounds, as substances that exhibit antioxidant properties, negatively affects the health of modern people, living in the metropolis, and people who need a special diet.

Experimental studies [6] show that phenolic compounds and flavonoids are safe and necessary for people with diabetes mellitus type II and endocrine disorders of various genesis.

The question of studying the content of flavonoids and phenolic compounds in chocolate is little studied and relevant, therefore, the purpose of the experiment was to study the content of phenolic compounds, flavonoids and iodine in chocolate for a special dietary direction.

A recipe for chocolate with natural sugar substitutes: stevioside and erythrol in combination with germinated soy flour, enriched with iodine, has been developed at the Department of International E-Commerce and Hotel and Restaurant Business of Kharkiv National University named after V. N. Karazin. Chocolate, made with the above ingredients, was the subject of research.

\section{Analysis of literary data and statement of the problem}

There are publications [7] about harmful effects of chocolate on human health. Chocolate consumption is linked to diseases, such as diabetes and obesity. With this in mind, many nutritionists advise people with high blood sugar, or to lose weight, to exclude chocolate from their diet by replacing white sugar with natural or synthetic sugar substitutes.

There is a well-known method of chocolate production [8], using rebaudioside A as a sweetener. The difference between the proposed method of chocolate production from well-known ones is the increased content of whole milk powder (by $2 \%$ ) and the use of soy phosphatide concentrate. The disadvantage of the proposed technologies is that non-traditional food ingredients are considered in terms of only improving the structure-forming characteristics of chocolate products. Scientists have paid little attention to increasing consumer value, as required by specialized products and principles of nutritiology.

There is a well-known method of dietary milk chocolate production [9], using, in addition to the classic food ingredients, mare's milk, roasted grated walnut kernels, dried fruits. The invention allows to obtain chocolate, which is a source of essential amino acids. The presence of dried fruit allows you to get chocolate with high levels of phenolic compounds and flavonoids. However, the disadvantage of the proposed method of chocolate production is the partial content of white sugar and the lack of essential micronutrients, especially iodine. Almost $20 \%$ of Europe's population is in deficit of it. The antioxidant potential of new products has not been studied. One of the methods to overcome the above difficulties may be the use of non-traditional recipe ingredients, namely: germinated soy flour, enriched with iodine, erythrol and stevioside.

Given that chocolate is a popular confectionery product among children and adults and can take a worthy place in the diet of modern human, it is necessary to conduct research, aimed at studying the content of mass fraction of iodine, phenolic compounds and flavonoids. Consumption of chocolate with the use of non-traditional raw materials will solve an important social problem: to maintain high efficiency in the pandemic, to resist diseases and environmental factors.

Purpose and objectives of the study. Study of the content of phenolic compounds, flavonoids, iodine in chocolate using non-traditional raw materials. To achieve this goal, the following tasks were set:

- to investigate the total content of phenolic compounds;

- to investigate the total content of flavonoids;

- to investigate the content of mass fraction of iodine.

\section{Materials and methods of the study}

The recipe of the developed chocolate for specialized nutrition is shown in Table 1. 
Table 1

The recipe of the developed chocolate for specialized nutrition

\begin{tabular}{cc}
\hline Recipe ingredients & Mass, $\mathbf{k g} \mathbf{( \% )}$ \\
\hline Grated cocoa & 700 \\
Flour of germinated soy, enriched with iodine & 10 \\
Cocoa butter & 275 \\
Stevioside & 2.5 \\
Erythrol & 25 \\
"Vanilla" flavor & 10 \\
Output, kg (\%) & 1000
\end{tabular}

A well-known recipe was used as a control one, the difference of which is the use of $710 \mathrm{~kg}(\%)$ of grated cocoa and the exclusion of germinated soy flour, enriched with iodine, from the recipe.

Characteristics of the used non-traditional recipe ingredients of raw materials. Erythrol is a polyhydric sugar alcohol, made from corn. The sweetness coefficient is 0.7 , the energy value is $0.02 \mathrm{kcal} / \mathrm{gr}$. According to the $\mathrm{FAO} / \mathrm{WHO}$ Committee, it is safe for human health. It is registered in the food industry as a food supplement, under the code E 968, [10]. Stevioside is a sugar substitute of natural origin. It is produced from the leaves of perennial herb «Stevia». Stevioside is registered in the food industry as a food supplement E 960, as a sweetener. Sweetness coefficient - 250. Energy value $-1 \mathrm{kcal} / \mathrm{g}$ [11]. Sprouted soy flour, enriched with iodine [12].

\section{1. Study of the total content of flavonoids}

The flavonoid content was determined spectrophotometrically on a Lambda $35 \mathrm{UV} / \mathrm{VIS}$ spectrophotometer "(USA). The absorption spectrum was taken at a wavelength of $510 \mathrm{~nm}$ in a cuvette with a liquid layer thickness of $10 \mathrm{~mm}$. Distilled water was placed in the reference cuvette. The calculation of flavonoids in $\mathrm{mg}$ of catechin (C)/100 $\mathrm{g}$ of product was performed on a calibration curve.

\section{2. Study of the total content of phenolic substances}

The studies were performed by the colorimetric method to determine the total content of phenolic substances using Folin's reagent. $0.25 \mathrm{ml}$ of a $50 \%$ aqueous solution of Folin's reagent, $0.50 \mathrm{ml}$ of saturated sodium carbonate solution and $4.00 \mathrm{ml}$ of distilled water were added to sterile $0.25 \mathrm{ml}$ tubes with $0.1 \mathrm{mg} / \mathrm{cm}^{3}$ chocolate extract. $0.25 \mathrm{ml}$ of distilled water was added to the control sample instead of chocolate extract. The mixture was kept for $25 \mathrm{~min}$ at $25^{\circ} \mathrm{C}$ with constant stirring to complete the reaction. The samples were centrifuged for 10 minutes at a speed of 2,000 rpm The content of phenolic substances in a clear solution of chocolate extract was determined by the spectrophotometric method using a spectrophotometer "Lambda 35 UV/VIS" (USA). The absorption spectrum was taken at a wavelength of $725 \mathrm{~nm}$ in a cuvette with a liquid layer thickness of $10 \mathrm{~mm}$.

\section{3. Study of the iodine mass fraction}

The mass fraction of iodine was determined using a voltammetric analyzer «AVA-2» (Russia), which is equipped with an indicator electrode, auxiliary electrode, type comparison electrode. A portion of the sample was treated with a solution of potassium hydroxide, burned on an electric stove, then using a system for microwave ashing «PHOENIX» (Daewoo, China). The resulting ash was mixed in water, neutralized to $\mathrm{pH} 4 \ldots 6$, centrifuged. The resulting mass was added to an electrochemical cup with a background solution and measured. According to the results, the mass fraction of iodine was calculated.

\section{Research results and their discussion}

The results of the study of the total content of phenolic compounds, flavonoids and the mass fraction of iodine in chocolate are shown in Table. 2.

Analyzing the experimental studies, it can be stated, that the total content of phenolic compounds in the control type of chocolate per $198 \mathrm{mg}$ of GA/100 $\mathrm{g}$ of the product is less compared to the sample of chocolate, where non-traditional raw materials were used. It is known [14], that phenolic compounds in the body are not synthesized, but come with plant foods and are included in 
the composition - adrenaline, thyroxine, serotonin. Scientists believe [15] that the total content of phenols is a determining indicator of the level of antioxidant activity of food systems. According to literature data [16], germinated soy flour has a high content of phenols, so it is possible to assume that due to its content the content of phenols in the test sample of chocolate increases.

Table 2

The total content of phenolic compounds, flavonoids and the mass fraction of iodine in chocolate

\begin{tabular}{cccc}
\hline Studied parameter & $\begin{array}{c}\text { Recommended } \\
\text { daily amount }\end{array}$ & Control & Experiment \\
\hline Phenolic compounds, mg of gallic acid/ $100 \mathrm{~g}$ of the initial raw material & $\leq 1000$ & $998 \pm 0.4$ & $1196 \pm 0.4$ \\
Flavonoids, $\mathrm{mg}$ of catethin/100 g of the initial raw material & $\leq 500$ & $214 \pm 0.4$ & $443 \pm 0.3$ \\
Mass fraction of iodine, $\mathrm{mcg} / 100 \mathrm{~g}$ & 150 & traces & $63 \pm 0.2$
\end{tabular}

Note* The recommended daily amount for a woman aged 30... 40 years of medium labor intensity, according to the source [13].

The obtained results correlate with the results of determining the total content of flavonoids. The developed types of chocolate exceed control samples by $229 \mathrm{mg}$ of $\mathrm{C} / 100 \mathrm{~g}$ of the initial raw material.

That satisfies $88.6 \%$ of the recommended daily amount. It is known, that flavonoids depending on the degree of oxidation of the propane fragment are divided into catechins, anthocyanins, chalcones, flavanones, flavones, flavonols. Which have a wide range of biological activity on the human body due to the fact that they participate in redox processes. Performing the antioxidant function, they show P-vitamin activity, choleretic, antispasmodic, diuretic, hypoglycemic, sedative, estrogenic action. Scientists who have studied berries and germinated grains have found that they contain a significant amount of catechins, anthocyanins and flavnones.

The developed type of chocolate is a carrier of $63 \mu \mathrm{g} / 100 \mathrm{~g}$ of iodine. It satisfies $42 \% \mathrm{of}$ the recommended daily amount, as required by the principles of nutritiology. Chocolate is enriched with iodine due to the fact that sprouted soy flour is a carrier of iodine. Analyzing the research results, the recommended amount of consumption of the developed chocolate, which is $100 \mathrm{~g}$ per day, was determined.

When consuming this amount, the human body will receive $20 \ldots 60 \%$ of the daily requirement for the studied substances.

The prospect of further research is to study the antiradical activity of the developed chocolate with a content of $10 \%$ germinated soy flour, enriched with iodine; because radicals are highly reactive substances that lead to cell mutations or death.

\section{Conclusions}

1. The total content of phenolic compounds has been studied. It has been found, that the control sample of chocolate is a carrier of $998 \mathrm{mg}$ of GA/100 g, and the test sample exceeds this amount by $198 \mathrm{mg}$ of GA/100 $\mathrm{g}$ of the initial raw material. This is $1196 \mathrm{mg}$ of HA/100 $\mathrm{g}$ of the product.

It has been substantiated, that the use of germinated soy flour, enriched with iodine, in the amount of $10 \%$ due to the reduction of cocoa mass increases the total content of phenolic compounds, which is an indicator of increased levels of antioxidant activity.

2. The total content of flavonoids has been studied. It has been found, that the control sample of chocolate is a carrier of $214 \mu \mathrm{g}$ of $\mathrm{C} / 100 \mathrm{~g}$ of the initial raw material, and the test sample exceeds this amount by $229 \mathrm{mg}$ of C/100 g, and is $443 \mathrm{mg}$ of HA/100 $\mathrm{g}$ of the initial raw material.

The use of germinated soy flour, enriched with iodine, in the amount of $10 \%$ provides a supply of flavonoids to the human body by $45.8 \%$ more than the control.

3. The content of mass fraction of iodine has been investigated. It has been found, that the developed type of chocolate is a carrier of iodine in the amount of $63 \mu \mathrm{g} / 100 \mathrm{~g}$. Only traces of mass fraction of iodine were found in the control sample of chocolate. It has been determined, that the use of germinated soy flour, enriched with iodine, in the amount of $10 \%$ due to the reduction of cocoa mass satisfies $42 \%$ of the recommended daily amount for a woman aged $30 \ldots 40$ years of average labor intensity. 


\section{References}

[1] Samokhina, G. O., Naumenko, N. V. (2016). Nutrition as the main factor of health maintenance. Problemy stareniya i dolgoletiya, 25 (2), 204-214. Available at: http://geront.kiev.ua/library/psid/t25/n2/Simakhina.pdf

[2] Biletska, Y., Djukareva, G., Nekos, A., Husliev, A., Krivtsova, A., Bakirov, M. et. al. (2020). Investigation of change of quality indicators of gluten-free bread during storage. Eastern-European Journal of Enterprise Technologies, 5 (11 (107)), 54-61. doi: https://doi.org/10.15587/1729-4061.2020.215019

[3] Biletska, Y., Ryzhkova, T., Babenko, V., Krivtsova, A., Plotnikova, R., Skyrda, O. (2020). Substantiating the use of sprouted beans flour in the production of sour milk products based on goat milk. Eastern-European Journal of Enterprise Technologies, 4 (11 (106)), 6-13. doi: https://doi.org/10.15587/1729-4061.2020.209514

[4] Nikitin, I. A., Bogatyryev, V. A., Mironchenko, Y. A., Lavrov, S. V. (2017). Development of chocolate technology for dietary purposes based on natural sweeteners. Proceedings of the Voronezh State University of Engineering Technologies, 79 (2), $153-158$. doi: https://doi.org/10.20914/2310-1202-2017-2-153-158

[5] Sokolov, A. N., Pavlova, M. A., Klosterhalfen, S., Enck, P. (2013). Chocolate and the brain: Neurobiological impact of cocoa flavanols on cognition and behavior. Neuroscience \& Biobehavioral Reviews, 37 (10), 2445-2453. doi: https://doi.org/10.1016/ j.neubiorev.2013.06.013

[6] Tabernero, M., Serrano, J., Saura-Calixto, F. (2006). The antioxidant capacity of cocoa products: contribution to the Spanish diet. International Journal of Food Science and Technology, 41 (s1), 28-32. doi: https://doi.org/10.1111/j.1365-2621.2006.01239.x

[7] Brcanović, J. M., Pavlović, A. N., Mitić, S. S., Stojanović, G. S., Manojlović, D. D. et. al. (2013). Cyclic voltammetric determination of antioxidant capacity of cocoa powder, dark chocolate and milk chocolate samples: correlation with spectrophotometric assays and individual phenolic compounds. Food Technology and Biotechnology, 51 (4), 460-470. Available at: https:// hrcak.srce.hr/114462

[8] Solomina, O. O. (2017). Pat. No. 115454 UA. Sposib vyhotovlennia shokoladu. No. u201700313; declareted: 11.01.2017; published: 10.04.2017, Bul. No. 7. Available at: https://uapatents.com/4-115454-sposib-vigotovlennya-shokoladu.html

[9] Sharmanov, T. Sh., Sinyavskiy, Yu. A., Makeeva, R. K., Akzholtaeva, Sh. N., Agadilova, A. B. (2015). Pat. No. 31594 KZ. Sposob proizvodstva shokolada. No. 2015/1010.1; declareted: 04.09.2015; published: 30.09.2016, Bul. No. 12. Available at: https://kzpatents.com/4-31594-sposob-proizvodstva-shokolada.html

[10] Eritritol - zamenitel' sahara novogo pokoleniya. Available at: https://1000.menu/table/25167-eritritol-zamenitel-saxara-novogo-pokoleniya

[11] Steviozyd - naturalnyi pidsolodzhuvach. Available at: http://ua.wellgreenxa.com/info/stevioside-natural-sweetener38923524.html

[12] Biletska, Y., Danko, N. I., Husliev, A. P., Babenko, V. O. et. al. (2020). Pat. No. 144555 UA. Sposib oderzhannia boroshna z soi. No. u202002483; declareted: 21.04.2020; published: 12.10.2020, Bul. No. 19. Available at: https://base.uipv.org/searchINV/ search.php?action=viewdetails\&IdClaim=271731

[13] Nakaz No. 1073. Pro zatverdzhennia Norm fiziolohichnykh potreb naselennia Ukrainy v osnovnykh kharchovykh rechovynakh i enerhiyi. Available at: https://zakon.rada.gov.ua/go/z1206-17

[14] Emelda, A. (2015). Polyphenol total content, IC50 and antioxidant activities of ethanol extract from some cocoa (Theobroma cacao) beans in South Sulawesi Indonesia. Journal of Chemical and Pharmaceutical Research, 7 (4), 1211-1214. Available at: https://www.researchgate.net/publication/301633452_Polyphenol_total_content_IC50_and_antioxidant_activities_of_ethanol_extract_from_some_cocoa_Theobroma_cacao_beans_in_South_Sulawesi_Indonesia

[15] Ibrić, A., Ćavar, S. (2014). Phenolic compounds and antioxidant activity of cocoa and chocolate products. Bulletin of the Chemists and Technologists of Bosnia and Herzegovina, 42, 37-40. Available at: http://www.pmf.unsa.ba/hemija/glasnik/ files/Issue\%2042/Issue\%2042\%20novo/42-7-Ibric.pdf

[16] Bykov, D. E., Makarova, N. V., Valiulina, D. F. (2018). Chocolate as a product for functional nutrition. Vestnik MGTU, 21 (3), 447-459. doi: https://doi.org/10.21443/1560-9278-2018-21-3-447-459

How to cite. Biletska, Y., Bilovska, O., Krivtsova, A., Huzhva, I., Nekos, A. (2021). Research of the content of phenolic compounds, flavonoids and iodine in chocolate using non-traditional raw materials. EUREKA: Life Sciences, 3, 41-45. doi: https://doi.org/10.21303/2504-5695.2021.001875 